\title{
Haplotype Diversity of COI Gene of Hylarana chalconota Species Found at State University of Malang
}

\author{
Dian Ratri Wulandari ${ }^{*}$, Ibrohim ${ }^{1}$, and Dwi Listyorini ${ }^{1}$ \\ ${ }^{1}$ Biology Department, Faculty of Mathematics and Science, State University of Malang, Malang, Indonesia
}

\begin{abstract}
Hylarana chalconota is a cryptic species of frog endemic to Java Island [1]. This species is small with long legs, and brown skin. The Snout-Vent Length (SVL) ranges between 30-40 $\mathrm{mm}$ for male and 45-65 mm for female. [4] Reports the existence of this species in State University of Malang, which was not found in 1995 [5]. Sampel \#1 displays spots in its skin, which does not exist in sample \#2. To reveal the haplotype diversity of COI gene in this species, we analyzed Cytochrome-c oxidase subunit-1 (COI) sequences of both samples. Using a pair of primers according to [6] both samples had 604 bp and 574 bp fragment length, respectively. These fragments showed polymorphism; with mutation position in sites 104, 105, and 124. Based on this result, we suggest that the two samples share a different haplotypes, proposed as UM1 and UM2.
\end{abstract}

Keywords: Haplotype, Hylarana chalconota, Cytochrome-c oxidase subunit-1 (COI)

\section{INTRODUCTION}

Hylarana chalconota is a cryptic species of frog endemic to Java Island [1]. Described originally from Java, Rana chalconota is reported from southern Thailand to Java, including Borneo and Sumatra and consists of at least seven species. Exsisting names are applied to three of these species, Rana chalconota (Schlegel) (Java and South Sumatra), Rana raniceps (Peters) (Borneo) and Rana labialis Boulenger (Peninsular Malaysia) [1]. Rana chalconota can be found at tropical and subtropical climate, with moderate or flat topography [2]. Rana chalconota is endemic to Java, without exact locality [3], and samples from other regions are needed because of sampling weakness [2, 3].

Rana chalconota is Sundaland frogs that breed along the stream of lowland forests, from primarry rain forests, swamp forests, to secondary forest [1]. Rana chalconota can be found from lowland up to above 1200 meter asl, frequently found near hum-

\footnotetext{
"Corresponding author:

Dian Ratri Wulandari

Biology Department, Faculty of Mathematics and Sciences, State University of Malang

Malang-Indonesia

E-mail: dianratriw@yahoo.com, listyorini.alj@bio.um.ac.id
}

-an habitat where the water exists, usually prefers stagnant water such as fish ponds [3]. This species has a slender, small to moderate- sized ranging between 30-60 mm snout-vent length for the adult. Toes and fingers are fully webbed to the distinct expanded tips. The general color is green above and white or cream-coloured below [1], with dark brown tympanum and long and slender legs. Their skin is coarsely granular [3].

Wulandari et al., (2012) [4] Reports the existence of this species in State University of Malang, which was not found in 1995 [5]. There are two types of Hylarana chalconota which exists in the campus, type \#1 displays spots on its skin, while type \#2 does not have spots. Study using Cytochrome-c oxidase subunit-1 (COI) for each samples found that length branches are different. Thus, further analysis to know the sequence of polymorphism and haplotype is needed.

\section{MATERIALS AND METHODS}

The study was conducted over four months from March to June 2012. Observation of frog was conducted in March by dividing the campus (UM) area into four sections. In the morning, observation was conducted at 6:00 to $10: 00 \mathrm{am}$, and in 
the evening at 18:00 to 21:00 pm. Morphological observations were carried out by observing the morphological and morphometric characters. Isolation of total DNA (whole genome) was done by taking part of toes and were then isolated using NucleoSpin Tissue DNA Isolation Kit, MachereyNagel, Germany. Using a pair of primerforward: Lep-F1 (5'- AT'T CAA CCA ATC ATA AAG ATA TTG G-3'), reverse: Lep-R1 (5'-TAA ACT TCT GGA TGT CCA AAA AAT CA-3'), with PCR cycles consisting of 1) initial denaturation at $94^{\circ} \mathrm{C}$ for 2 minutes; 2) 5 cycles consisting of denaturation at $94^{\circ} \mathrm{C}$ for 40 seconds, annealing at $45^{\circ} \mathrm{C}$ for 40 seconds, and extension at $72^{\circ} \mathrm{C}$ for 40 seconds; 3) 35 cycles consisting of denaturation at $94^{\circ} \mathrm{C}$ for 40 seconds, annealing at $51^{\circ} \mathrm{C}$ for 40 seconds, and extension at $72^{\circ} \mathrm{C}$ for 1 minute, and; 4) the final extension at $72^{\circ} \mathrm{C}$ for 5 minutes [6].

Electrophoresis was performed using $1 \%$ agarose gel and sequencing was performed at the Eijkman Institute for Molecular Biology Jakarta with ABI Big Dye Transilluminator through 3130x1 and a 3130 Genetic Analyzer. Genetic analysis was performed by using the software of BioEdit, DNA Baser, BLAST, Clustal X, and Mega 5. Construction of the phylogenetic tree was conducted by Maximum Likelihood (ML), Neighbor Joining (NJ), Minimum Evolution (ME) and maximum parsimony (MP) with bootstrap of 1000 replicates and Kimura-2 parameter, thus selected the best. Then, further analyses to determine the sequence poly-morphism and to see haplotypes were done using DnaSP and ahaplotype network

\section{RESULTS AND DISCUSSION}

Based on the morphological characters, the SVL (Snout Vent Length) of sample \#1 is $43 \mathrm{~mm}$, and sample 2 is $45 \mathrm{~mm}$. Sample 1 displays spots on its skin, which does not exist in sample 2 (Figure $1)$.

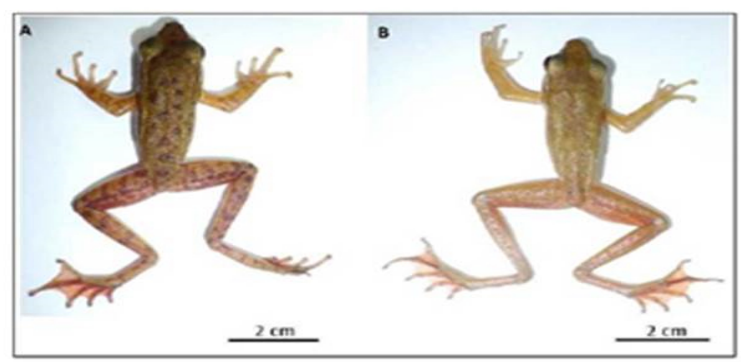

Figure 1. A) Sample, B) Sample 2

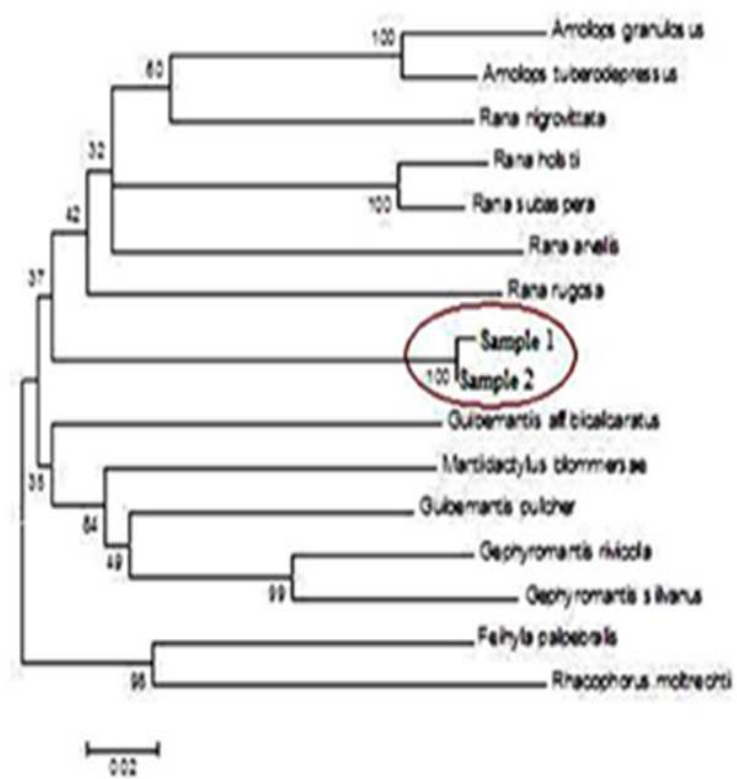

Figure 2 Topology of the phylogenetic tree Sample 1 and sample 2 using Maximum likelihood methods with the bootstrap repetition 1000 and Kimura-2 parameter

BLAST analysis of COI fragment amplified 604 bp from sample \#1 reveals 93\% query coverage with $81 \%$ sequence homology; COI fragment amplified 574 bp from sample \#2 reveals 95\% query coverage with $81 \%$ sequence homology. Sample \#1 and sample \#2 spare 0.54\% intraspecies variation. According to [6] both samples are in the same species. Phylogenetic analysis using ML, NJ, $\mathrm{ME}$, and MP; the three methods of ML, NJ, and ME show that all situate sample \#1 and \#2 in different branch length, with sample \#2 in a longer branch (Figure 2 red circle). Sample \#1 and sample \#2 is closely related to Rana rugosaand is included in the family Ranidae. Branch length of sample 1 and sample 2 is further analyzed using DnaSP and haplotype network to determine polymorphism sequences and haplotype. Polymorphism is found in site 104, 105, and 124 with two distinct haplotypes, i.e. haplotypes 1 for sample \#1 and haplotype 2 for sample \#2. Based on this result, we suggest that the two samples have different haplotypes, proposed as UM1 and UM2.

\section{CONCLUSIONS}

The two types of frog found in UM are in the same species, yet they share different haplotypes 


\section{ACKNOWLEDGMENT}

The author would like to thank Kurniawan, N., D. T. Iskandar, D. A. Rahayu, and L. Nazar for countless assistance and support during this research

\section{REFERENCES}

1. Inger RF, Struart BL, Iskandar DT (2009) Systematics of a widespread Southeast Asian frog, Rana chalconota (Amphibia: Anura: Ranidae). Zoological Journal of the Linnean Society. 155:123-147.

2. Inger RF (1999) Distribution of Amphibians in Southern Asia and Adjacent Islands, in Patterns of Distribution of Amphibians, Editor: Duellman, W.
John Hopkins University Press.USA. 445-470.

3. Iskandar DT (1998) The amphibians of Java and Bali, Research and Development Centre for Biology-LIPI. Bogor.

4. Wulandari DR., Habibi M, Ibrohim, Listyorini D (2012) Observation of Frog Species in State University of Malang as a Preliminary Effort on Frog Conservation, Proceedings of the International Conference Global Resource Conservation Brawijaya University.

5. Mashuri T (1995) Inventarisasi jenis katak di kampus IKIP Malang. Thesis unpublished.

6. Smith MA, Poyarkov JRA, Hebert PDN (2008) DNA Barcoding CO1 DNA Barcoding Amphibians: Take The Chance, Meet The Challenge. Molecular Ecology Resource. 8: 235-246. 